\title{
Urban green infrastructure as a tool for controlling the resilience of urban sprawl
}

\author{
José G. Vargas-Hernández ${ }^{1}$ (D) . Justyna Zdunek-Wielgołaska ${ }^{2}$
}

Received: 28 August 2019 / Accepted: 27 January 2020 / Published online: 31 January 2020

(c) The Author(s) 2020

\begin{abstract}
This paper is aimed to analyze the existing relationships and controlling functions between the urban green infrastructures on the resilience of the urban sprawl. The analysis begins questioning whether urban sprawl sustainable growth can be controlled after achieving urban supported by urban green infrastructure. The analytic method used is based on developing a conceptual and theoretical framework of reference to review the literature on the main variables of the research: Green infrastructure, resilience, and urban sprawl. It is concluded that while it is difficult to find linear causality in a direct relationship among the variables of the analysis, it is supported by the existence of more holistic connectivity leading to the controlling of the urban sprawl. The analysis suggests that a holistic approach is required to build urban resilience based on green infrastructure by addressing a fuller range of ecosystem disturbances and disasters, to create the outcomes that develop the environmental and ecological benefits of urban spectrum of ecosystem disturbances and disasters, to create the outcomes that develop the environmental and ecological benefits of urban sprawl.
\end{abstract}

Keywords Green infrastructure · Urban sprawl · Urban resilience · Holistic approach · Urban ecosystems

\section{Introduction}

Urban sustainable growth is interlinked with eco-action, leading to socioecosystems, green infrastructure, and ecological resilience. Urban biodiversity in ecosystems provides human beings with ecosystem services and goods including urban green spaces, green infrastructure, vacant lands and lots, blue spaces, etc., to support biodiversity and

Justyna Zdunek-Wielgołaska

justynazdunekwielgolaska@gmail.com; justyna.wielgolaska@pw.edu.pl

José G. Vargas-Hernández

jvargas2006@gmail.com; jgvh0811@yahoo.com; josevargas@cucea.udg.mx

1 University Center for Economic and Managerial Sciences, University of Guadalajara, Periférico Norte 799-Edif G201-7, Núcleo Universitario Los Belenes, 45100 Zapopan, Jalisco, Mexico

2 Faculty of Architecture, Warsaw University of Technology, Koszykowa 55, 00-659 Warsaw, Poland 
socioeconomic development. Urban biodiversity is decreasing over the years due to population growth, land-use changes, climate change, invasive species, etc. Urban land use, environmental and climate changes are driven by the densification of population expansion and development and are placing mounting pressure on urban biodiversity, ecosystem services, and resilience, leading to dysfunctional urban sprawl.

The concept of ecological resilience is emerging in the middle of the challenges posed by climate change and the growing urbanization processes. Urban sprawl is related to the socioecosystem is complex and unpredictable ecological resilience because it includes the interaction of the social, psychological, physical, structural, engineering, natural, environmental and other resilient systems to build up and influence each other on the resilient city development.

Socioecosystems and green infrastructure provide benefits in ecosystem services to improve human health and critical environmental and socioeconomic services. Environmental performance can integrate green infrastructure design, biodiversity, and ecosystem services into the green projects aimed to achieve economic and environmental benefits in energy, water, air quality, transportation and logistics, waste and materials, climate, bioeconomics, etc.

Urban green spaces and infrastructure bring economic social and environmental benefits such as the mitigation of climate change and heat island effect, reduction and absorption of pollutants, maintenance of natural resources and landscape, increasing the attractiveness and beauty of urban landscape, connection between nature and sense of place, improvement of quality of life, etc.

Green infrastructures and spaces offer benefits addressing multiple challenges to become economically viable for urban recipients properly recognized and quantified. Well-functioning and healthy ecosystem urban services contribute to the resilience of the city. It is necessary to ensure that urban ecosystem services are resilient and at the same time contribute to building the resilience of cities. To achieve this is required to have resilient urban natural spaces to increase the quantity, quality, and diversity and to expand the use of natural spaces and urban green infrastructure.

Despite the multiplicity of concepts and definitions of urban resilience, however, in the ecosystem services, it is defined as the ability of the urban sprawl socioecosystem that is subject to disturbances to retain its essential structures functions. Urban sprawl ecosystems perform multiple functions among which are the ecosystem services to benefit the building of resilient cities to impacts disasters, climate change, and other disturbances. Urban sprawl ecosystems are used to reduce the impacts of natural disasters and hazards and enhance adaptive capacities to strengthen the qualities of resilient cities.

The scope of hazards associated with global climate changes has severe impacts on urban sprawl. To successfully combat these changes, it is crucial to define goals precisely and define appropriate tools. In this environmental context, the use of ecological urban planning seems indispensable. By creating an appropriate framework for spatial policy based on ecological assumptions, it is possible to halt the negative effects of urbanization, and in a longer perspective even to their gradual withdrawal.

This paper is aimed to analyze the existing relationships and controlling functions between the urban green infrastructure on the resilience of the urban sprawl. It begins by reviewing and analyzing the conceptual and theoretical approaches of green infrastructure, to continue with urban resilience and then analyzing the interrelationships of these two variables to be used as a controlling the urban sprawl. 


\section{Urban green infrastructure}

The modernist urban development model characterized cities as large-scale, planned infrastructures operated by professionals in government departments (Graham and Marvin 2001; Pincetl 2012). The modernist and progressivist urban development model has tools of the urban zoning, infrastructure assimilation of immigrant populations and equitable distribution of urban services (Gandy 2003; Graham and Marvin 2001; Melosi 2000). These tools were used as an assumption of modernity in the renovation of the City Beautiful Movement. The resilience of a particular habitat can lead to ecosystem services connected to a specific state of the habitat.

Green infrastructure has been defined as natural vegetative systems, green methodologies, and technologies replicating the ecosystem functions to benefit society. Green infrastructure includes any punctual urban green area and element as well as the ecological intervention adopted by city authorities which are crucial for the sustainable growth of an urban community, for the improvement of quality of life of residents, to provide ecosystem services to benefit all the human beings, and achieve environment and sustainability objectives. Green infrastructure is created and developed of natural resources and elements in a good quality built environment based on strategic intervention in the feasible private and public lots and properties.

Urban natural and green spaces and green infrastructure combined with engineered infrastructure are cost-effective to provide environmental benefits such as improving air quality, reducing soil erosion, offsetting the urban heat island effects, help to manage water quality, provide physical and mental benefits, etc. Urban ecosystems and green infrastructure provide critical ecosystem services useful to improve human well-being and health while at the same time buffer against natural disasters and disturbances.

Socioecosystems and green infrastructure provide benefits in ecosystem services to improve human health, and the critical environmental and socioeconomic services. Urban green infrastructure provides ecosystem, cultural and recreational services such as gardening, birding, biking, fishing, freshwater, fresh air, playgrounds, etc. Green infrastructure can combine several urban functions in one instrument for promoting benefits and addressing some challenges, such as wetlands that are used for water retention, recreation, city aesthetics, cooling and water purification.

Preservation and conservation of natural green infrastructure is a critical factor to ensure a resilient supply of ecosystem services. Nature-based solutions in urban green areas may overlap with ongoing activities in green infrastructure of the urban agenda to support urban economic, social and environmental challenges. Urban green infrastructure engages with the urban socioecosystem to fulfill societal and community goals.

The resilience of engineering system and green infrastructure resilience is related to geophysics-seismic engineering, safety and security engineering, contingency infrastructures (Boin and McConnell 2007; Bruneau et al. 2003; Fritzon et al. 2007; Hellström 2007, and others). Different dimensions determining resilience reveal that inhabitants of prone areas of disaster, the resistant buildings and green infrastructures are indicators of resilience, including psychological resilience. Building resilience of ecosystems and ecosystem services can be based on green infrastructure and technology, response biodiversity and adaptive management approach.

The components of the resilient infrastructure are robustness characterized as the system capability to resist a specific event; recovery as the systems capability to recover after a crisis, and resourcefulness with the current resources developed to support the robustness 
of the facility and the new resources to support the recovery of the system. Infrastructure resilience is related to the notions of risk, infrastructure vulnerability and criticality assessing the relevance of infrastructure. Complex green infrastructures established in multi-risk environments require developing risk assessment methodologies to estimate resilience and criticality of facilities with indexes of vulnerability, criticality and resiliency in an overall risk index for each critical infrastructure, representing the first level of resilience assessment (Fisher and Norman 2010).

The environment can cause the living fear caused by any dangers from disasters. Following natural and human-made disasters, resistance, absorption, recovery and stability define the resilience of any green infrastructure, social and environmental complex systems. Resilience analysis expands beyond the technical concepts is the relevance to the resistance of green infrastructure, to human-environment-resilience systems. Ecological resilience interacts with social resilience and green infrastructure/engineering resilience.

The impacts of natural disasters are possible to mitigate but not to stop them despite the reliable and accurate data and information available related to the severity of the socioecosystem, green infrastructure and environmental resilience. Disaster/crisis management of urban settlements has serious implications in resilient cities and includes different kinds of critical green infrastructures such as water, sewage and waste systems, communication and transportation systems, healthcare and emergency services, commercial facilities, etc.

Contacts between communities of practice should be enhanced at local, regional and national levels to exchange knowledge and experiences on urban green infrastructure, biodiversity, and ecosystems. City labs framework is implemented using urban local data and by involving stakeholders and the community working on green infrastructure in the process of specific issues.

The development of green infrastructure networks of basic exosystemic services with ecological value for urban resilience to be used by urban communities and neighborhoods can become effective as lineal or punctual elements. The green infrastructure network consists of links and nodes, the origins and destinations of natural and restored ecological and ecosystem flows such as the urban green spaces and areas. Green infrastructure is different that ecological network by its multi-functionality which combines both ecosystemic and functional aspects such as mobility, open public green spaces, and recreation areas. Green infrastructure is the network of multi-functional green spaces, newly identified or existing, rural or urban, supporting natural and ecological processes.

Green infrastructure is a critical component for community health and quality of life. Urban green spaces and parks can form a more connected system able to share the support of multiple-function green infrastructure instead of grey infrastructure, integrating different functions and providing other socioecosystem services and environmental benefits, improving the ecosystem resilience while reducing the impacts of disturbances and disasters. Horizontal and vertical levels of governance are supported by local urban policy resulting from the interactions of local researchers, practitioners, and stakeholders who can contribute to deploying green infrastructure in urban contexts. Urban ecosystem services production assessed by the urban green infrastructure should enable planning and management how can be improved.

Integration of green and natural infrastructure and eco-biodiversity guidelines into urban sustainable planning and design in sites and streetscapes would recreate the natural habitat and their functions. Urban infrastructure planning and development should achieve climate resilience through more effective social inclusive policies aimed to protect vulnerable groups of the population. Infrastructure resilience assessment is a relevant component of the planning and monitoring system. 
The green infrastructure strategy adopted by some governments to support policies in specific areas such as land-use regulations, mitigation and adaptation of climate change, renewable energy, waste management, urban transport and logistics, disaster prevention, etc., which contribute to the improvements of natural resources and processes in urban sustainable planning.

Government policies focused on incentive the development of environmental sustainability and the establishment and deployment of natural green infrastructure to be implemented by the local government. Efficient urban policies must support green infrastructures with high density and coverage ratio to be implemented in green spaces considering urban local public and private interests and offering benefits in ecological value to all involved stakeholders. Implementation of urban green development policies is crucial to promote research and innovative technology development and to facilitate access to finances to support green infrastructure projects. Green infrastructure can be improved in public and private properties subject to the effectiveness of green public policies.

Building system resilience is supported by investments and measures in safety engineering developing capabilities to manage the emergency and risks of disturbances and disasters. Regulation of ecosystem services to build resilience by the adoption of ecosystem management and investing in green infrastructure and technology are the factors that may contribute to improving the quality of life. Urban development regulatory compliance should ensure that the new urban developments must integrate natural resources and features to capitalize on opportunities for the creation and enhancement of urban green infrastructure and natural scapes.

Green interventions in infrastructure require financial investments which may be compensated with public green policies to provide economic incentives and with the reduction of costs and expenses derived from the performance improvement. Investments on urban green infrastructure and socioecosystems provide low-cost solutions to challenges of urban resilience compared to traditional solutions. The cost of green infrastructure in these projects should be lower than the traditional grey infrastructure. Ecological taxes can be an integrated tool to support actions in greening businesses and markets, sustainable infrastructure development, sustainable investment in specific natural capital of green sectors and sustainable consumption.

Following the example of some Italian cities, local government can provide economic incentives offering tax benefits to reduce secondary infrastructure, to fight landscape degradation. Subsidy and incentive programs may be aimed at new developments integrated with natural features and urban green infrastructure. At the local scale, some urban green development policies can be arranged to provide some kind of bonus to the creation and establishment of green infrastructure that can be deducted from income taxes aimed to level off the investments in green infrastructure.

\section{Urban resilience}

Resilience is a conceptual framework that had to emerge from ecology and applied to ecosystems (Holling 1973). The conceptual framework of resilience is incorporated in the analysis of social systems as community resilience in ecosystem services, which refers to the ability of the community to recover from disturbances without external assistance (Cutter et al. 2008; Mileti 1999). Ecosystems may be resilient to some kinds of disturbances but not others. Resilience is related to the provision of ecosystem services. 
The resilience in ecological dimensions is incorporated into the core of ecological systems formed by the ecosystem services and natural capital as an integral part of social initiatives and research frameworks to develop resilience thinking (Plummer and Armitage 2007). Although greater ecosystem resilience is related to greater biodiversity, not all resilient ecosystems are biodiverse (Wieski et al. 2010). Ecological resilience is a nonlinear dynamics of ecosystems (Holling 1973) defined by the amount of disturbance that the ecosystem withstands in self-organized structures and processes or alternative stable states. Dynamic changes involve adaption to new conditions of socioecosystems resilience allowing for adaptation. Socioecosystems are the ability "to continually change and adapt yet to remain within critical thresholds. This adaptability is part of resilience." Folke et al. (2010).

Holling defines resilience in ecosystems as the measure of persistent systems and of their ability to absorb change, disturbance and still maintain the same relationships between populations and state variables (Holling 1973, p. 14). The resilience of ecosystems relates to the resilience of human communities although both do not correlate with each other. A non-resilient ecosystem can be linked to a resilient community.

Urban resilient, equitable and sustainable urban spaces are dependent on the ability of the system to maintain socioecological functions (Alberti et al. 2003). Urban ecological resilience has the meaning of adaptation and adjustment (Wu and $\mathrm{Wu} 2013$ ) of complex, adaptive and self-organizing socioecological systems (Gunderson et al. 2002). It does not require an equilibrium (Kowarik 2011). Resilience within the operationalization of ecological systems, and natural capital is described as the capacity of social-ecological systems to cope with abrupt changes on variabilities, disturbances and hazardous events.

General resilience requires management capacities to cope with the challenges of different types of disturbances (Adger et al. 2005; Anderies et al. 2006; Walker and Salt 2006, 2012). Socioecosystem resilience is a conceptual framework to manage complexity and uncertainty of the systemic dynamics affected by long-term disturbances and stresses. The general ecosystem's resilience under a range of circumstances has attributes and properties to be increased to maintain diversity, variability and redundancy.

The socioecosystem resilience is influenced by management actions that should manage the ongoing stresses and shocks of natural resources, either on specific resilience when sources of disturbance are identified or general resilience when disturbances are not identified. The socioecosystem management for a specific resilience can implement measures using knowledge to design plans to face the specific types of disturbances to reduce vulnerability, minimize damage and increase the level of socioecosystems resilience.

Systems resilience has persistent structural and functional regimen shifts after any disturbance. Critical slowing down applied as an indicator of ecosystem resilience might be the rate of recovery when it decreases as a regime shift is approached (Scheffer et al. 2012; van Nes and Scheffer 2007). If the resilience decreases, a regime shift may have more probability to increase.

Increasing systems resilience reduces the risks of regimen shifts. A system is resilient if the identity and features of the systems persist after the disruption and consequent reorganization. Decreasing or increasing resilience contributes to the system dynamics knowledge, uncertainty, complexity and variability and feedbacks of system components (Walker and Salt 2006). Negative feedback in the bio-ecosystem can increase resilience by perpetuating continued existence, offsetting the disturbance's effect, and the system is pushed away from equilibrium ecosystems that have strong negative feedbacks tend to be resiliently maintaining the conditions in the face of long-term disturbances and long stresses. 
The concept of resilience can be now applied to natural socioecological systems, resource management, economics, management, social systems, organizational theory, sociology, psychology, engineering, etc. (Berkes and Folke 1998; Berkes et al. 2003). The different meanings of resilience are related to assumptions that reflect different aspects of stability with single or multiple equilibria in the system and giving support to different policies and actions. The resilience of a socioecosystem in multiple equilibria is the ability to absorb disturbances without crossing a critical threshold returning to the original equilibrium state (Carpenter et al. 2001; Gunderson and Pritchard 2002; Holling 1973, 2001). Resilience also emphasizes other conditions beyond the steady state and instabilities form another instability domain (Hart and Milstein 1999).

Resilience is a concept useful to understand and manage urban settlements as dynamic, complex and adaptive systems (Musacchio 2008; Pickett et al. 2013). The most contemporary concept of resilience shows a dynamic contingency of the ecosystems in continuous or periodic evolution of an equilibrium of the natural world based on ecological assumptions. Resilience relates to the integrity of the natural system which tends to be more diverse and able to cope with change.

Resilience is the behavior of dynamic systems with disturbances that can be absorbed by the system and without changing state and maintaining the equilibrium. Social ecosystem resilience has as an essential component of the changes in the adaptability of human behavior (Folke et al. 2010). Human systems learn and adapt their behavior to maintain socioecological system resilience. Resilience in socioecological systems includes human behavior as part of all the ecosystems and can modify the feedbacks with the environmental conditions in such a way that it differs from the resilience of ecosystems where humans do not intervene (Berkes et al. 2003; Walker et al. 2006).

Resilience is the capacity of social, economic and environmental systems to cope with hazardous events, trend, and disturbances and responding and reorganizing to maintain their essential function, identity and structure while maintaining the capacity for adaptation, learning, and transformation, according to the Intergovernmental Panel on Climate Change (IPCC 2014, p. 40). Changes in environmental and social conditions influence resilience.

Resilience is the capacity of a system to adjust to internal and external shocks and disruptions and still maintain its structure and processes (Gunderson et al. 2002a; Gunderson and Holling 2002).

Resilience is the ability to adjust to internal and external structural disruptive shocks of a complex system that can be responded through the adaptive cycle model (Redman and Kinzig 2003). Resilience is the ability of a system to be in equilibrium with its environment despite the disturbances (Peterson et al. 1998). Resilience is the time that an ecosystem in equilibrium requires after perturbation to return to a steady state (Yaverbaum 1989). Resilience is concerned with capacities to adjust and respond to systemic change through time (Holling 1973).

Resilience is also considered as the time of return from perturbation to a stable state. Resilience is the system's ability to meet the social norms of sustainable goals (Ernstson et al. 2010). Resilience is a tool to evaluate the capacity of interactions affecting urban systems and their contextual changes (Brand and Jax 2007; Folke et al. 2002; Evans 2011). Resilience evaluates existing and anticipated future climate change on human security impacts associated with weather and natural disasters and their social and economic shocks. Resilience is a non-normative tool useful to understand the changes in complex systems promoting or inhibiting the goals of sustainability (Brand and Jax 2007). 
Resilience is a feature of the equilibrium paradigm based on ecological assumptions and predominance of structural stability and change of ecological systems (Pickett et al. 1992; Pickett and Ostfeld 1995). A resilience city has as components the sustainability goals, mechanisms to promote these goals and adaptive capacities management (Chapin et al. 2009). Adaptive capacity is the process that modifies ecological resilience. The ecological urban design takes the adaptive cycle as an ecological insight (Czerniak 2001; Musacchio 2009) that urban designers employ as adaptive and resilient urban plans (Pickett et al. 2011; Spirn 2012).

The different types of resilience are based on assumptions based on multiple stable states. Resilience assumes only one stable state despite the vulnerability to the ecosystem and climate changes. Resilience is a property mediating transitions among multiple stable states or stability domains of ecosystems. Multiple equilibria resilience also known as ecological resilience (Holling 1996) is focused on the disturbance magnitude of the socioecological system which usually is absorbed without returning or shifting to a new equilibrium (Walker et al. 2004).

The ecological concept of resilience bounces back after some perturbations. The ecological resilience results from evolutionary processes of ecosystems generating the interactions between the different species, communities and physical environment (Holling 1973; Levin 1998; Walker et al. 2006). Ecology studies disturbance and recovery, and resilience is a predictable capability to recovery to a previous state of disturbance. Ecological resilience structure processes across the functional biodiversity, different levels of scales, renewal and reformation sources. Interconnections between the biodiversity provide resilience when local populations are recolonized after extinction events. Increasing biodiversity maintains the stability of the system and enhances resilience (Folke et al. 2004; Tilman and Downing 1996).

Resilience is related to species diversity in such a way that diverse ecosystems may contain more species well responding to diverse disturbances and despite this, maintaining the system functioning (Tilman et al. 1996, 2005). The relationship between ecosystem resilience and biodiversity takes different models and forms depending on the mechanisms which can be linear, presence of keystone species and redundancy model in which the functions are duplicated by other species.

There is a debate on whether the increasing resilience of high species biodiversity contributes to socioecosystem stability (Ives and Carpenter 2007; McCann 2000; Naeem 2002a, b; Rooney et al. 2006). May (1974) has demonstrated that greater biodiversity leads to lower ecosystem stability, although the empirical evidence supports that greater diversity of species leads to greater stability of the system (Tilman 1996; Tilman and Downing 1994; Tilman et al. 2006).

Resilience and competitiveness in any green economic sector require efforts to harness traditional knowledge aimed to preserve the genetic biodiversity of natural resources in the ecosystem. Economic diversity increases the resilience of socioecosystems. The bio-diversification of sectors influences economic resilience (Simmie and Martin 2010). Resilience and green economic growth and development are complementary agendas to be pursued by urban communities in order to harness more benefits and value.

Ecological resilience is measured by the disturbance magnitude absorbed when the system redefines its structure and controlling behavior by changing variables and processes (Hart and Milstein 1999). Resilience is measured for the movement from the equilibrium of the system and the time of returning. In ecological resilience, the measure of stability is the return times, described by Holling as the engineering resilience (Heerwagen et al. 1997). 
Engineering resilience is the speed of a system returning to equilibria after disturbance, a concept that is related to resistance or the ability of the system to recover equilibrium after being disturbed. The engineering resilience is the equilibrium in situations of a legitimate desired stable state. A resilience with a single equilibrium, also known as engineering resilience, focuses more on the time to return after any disturbance (Holling 1996). Resilience in the non-equilibrium paradigm cannot return to a stable and fixed state in a resilience alliance, which is the ability to adjust to changing and unstable conditions.

The Resilience Alliance integrates diverse forms of social learning and knowledge, systems thinking, participatory approaches and adaptive management (Dyball et al. 2007). Security and operational resilience of environmental and economic variability and shocks ensure that the activities of business do not have a negative impact. The vagueness of resilience limits its utility in environmental management, but it is a useful boundary concept for other transcending disciplines (Brand and Jax 2007).

Ecological resilience initiatives have been developed to be applied to industry and businesses that are more dependent on natural capital and ecosystem services (MA 2005; Hanson et al. 2012). High fixed wealth in connected systems is associated with a low ability to adapt to disturbances or low resilience. However, if wealth is mobilized and the disturbed systems are built and natural capital is released, resilience is abundant.

Social resilience is the ability that communities develop to recover from external shocks to their social infrastructure (Adger 2000). Social resilience is depending on activities in the local ecosystems that reduce ecological resilience and sustainability through the loss of ecosystem services of formal and informal social institutions. Societal resilience requires corporate dependence that has an impact on ecological services (Hanson et al. 2012).

The term resilience has social and political connotations in sustainability (Brand and Jax 2007). Resilience is considered the response of the socioecological system to the variability of adverse events. Climate change increasing the frequency of extreme events is a greater challenge than gradual warming to social-ecological resilience. Resilience is a response to economic, social, cultural and environmental variability.

Resilience supports the wider society, communities and immediate impacts of disasters resilient societies are dependent upon the ecosystem's resilience, sustainability and security in the flow and delivery of ecosystem services.

Global resilience is central to global food, nutrition security, and climate warming. Climate change is having impacts on global agroecosystems and related ecological services as in the food security crisis. The calculation of resilience in food systems proposed by the UN FAO (2012) considers access to basic needs and local incomes. Resilience is a required element for sustainability in the UN post-2015 Sustainable Development Goals. For others, resilience detracts from sustainable development efforts (Hussain 2013) difficult to be implemented and measured in the policy context due to its ambiguity (Grünewald and Warner 2012).

The international organizations have limitations in environmental governance for supporting the greening growth and resilient growth for developing countries. Regional resilience in place-based context ensures competitive strategies for environmental and social dimensions. Resilience is the ability of the region to experience economic success, socially inclusive within environmental limits and riding global economic punches (Bristow 2010, p. 153).

Ecological resilience is linked to institutional and community capacities to cope with economic, social, environmental and health challenges. The community resilience to potential hazard events is determined by the necessary resources to being capable of organizing itself both prior to and during times of need. Some communities that have 
been affected by famine and drought have demonstrated that native seeds stocks maintain the resilience of the seed system and the food system among vulnerable populations (McGuire and Sperling 2011).

Approaches to quantifying resilience in ecological communities are elusive and measures require knowledge of the system (Holling 1973, p. 20). Well-managed and healthy ecosystems in resilient communities are better prepared to cope with natural disasters, consequences of erratic weather and climate change patterns reducing the impacts of these vulnerabilities. The resilience of ecosystems can be impacted by the resilience of human communities resulting in changes, for example in land use, hydrology, etc. Human communities overly reliant on a small set of industries may become locked into some patterns of behavior adding stress to ecosystems and defaulting to maintain the resilience of the socioecosystem.

The four attributes for ecological resilience proposed by Folke et al. (2004) are the latitude or the amount of change before the system can recover, resistance as the degree of a system is not affected by pressures, precariousness, or the system's attributes and its current trends and proximity to thresholds; and cross-scale interaction, or the states and dynamics of multiple scales affecting the attributes.

The dimensions of resilience are the core meaning and the operationalizing models which can be applied to adaptive models to enhance urban sustainability (Peterson et al. 1998). The nature of resilience emerges from the dimensions of capital as an interaction of accumulated wealth and connectivity. The capacity for resilience is likely to be low at high connectivity with the predominance of conservative system components.

Low capital and institutional inertia are traps that may thwart resilience (Pelling and Manuel-Navarrete 2011). Vulnerability to system disruption is another dimension of resilience that results from complexity and connectivity (Cumming et al. 2010; Turner et al. 2003). More than the transdisciplinary utility of resilience, it is the capability and ability of an element to return to a stable state after a disruption (Bhamra et al. 2011; p. 5376).

In the ecological theory of succession, resilience links external and internal drivers of the system structure and activities required to adjust the ecosystem after the disturbance has disrupted (Pickett et al. 2013; Holling 1973). Ecological and evolutionary resilience is most useful to an equilibrium or engineering approach (Gunderson and Holling 2002a). The assumptions of ecology in urban design underlining the models concerning urban resilience (Cadenasso and Pickett 2008) are based on open systems inclusive of humans, their effects and artifacts susceptible to disturbance, externally regulated, path-dependent and contingent dynamics and with several alternative stable states (Pickett et al. 1992).

The characteristics of resilience in socioecological systems are the control of the system change, the self-organization capacity of the systems and the adaptation and learning capacity (Resilience Alliance 2006). Self-organization is the result of resource management with the participation of local residents which may lead to adaptive learning and greater resilience (Olsson et al. 2004). A high degree of resilience is associated with the capacity to reorganize resources accumulation in a conservative structure.

Resilient social-ecological systems intentionally adopt to the appropriate adaptive system. The resilience of the social ecosystem is more relevant, although the knowledge is more limited than the knowledge of any resilience of ecosystems. The resilience analysis of any socioecosystem is more abstract and not offers practical advice. The resilience adaptive cycle model incorporates adaptive economics, social and biophysical capacities in interaction with the social ecosystems. Cycles resulting from resilience can stimulate urban environmental design (Barnett and Margetts 2013; Pickett et al. 2013; Shannon 2013). 
When socioecological systems or communities lacking resilience in times of natural disaster or conflict, they collapse into a qualitatively different state controlled by a different set of processes (Resilience Alliance 2006). Restoration to the previous state is a complex system requiring strategies, policies and tools to integrate ecological and social sciences for building resilience in socioecological systems. Building modularity preserves overall resilience (Levin 1999). Ecosystem restoration is related to resilience when returning to pre-disturbance conditions. Ecosystem restoration from a disturbance is linked to ecosystem resilience.

The shift in the paradigm derives in the application of the ecological resilience linked to urban systems. Urban resilience and sustainability are linked to support sustainable urban transformation considering that urban and rural settlements and livelihoods are not isolated from each other. Resilience poises a system when capital shifts from available to allocated and connectivity shifts between dynamic and fixed. It should be avoided the extremes from polarization from low capital and productivity, rigid polarization of connectivity and capital, low capital in scattered connections and capital mobilization with poor institutional connections.

Resilience traces an ecosystem through the adaptive cycle the activities of institutions, social groups and the resources inter playing in heterogeneous spatial urban areas based on a sustainable development plan (Kauffman 2009). Adaptive capacity is an adjustment mechanism of the emerging resilience to complex dynamic systems responding to the development of capital and connectivity over time and depending on the magnitude of shocks and capacities. The degree of resilience is determined by the model of adaptive capacity (Walker and Salt 2006). Resilient adaptive processes maintained by institutional and social choices in the context of sustainability deal with an adaptive system.

At the center of the building of resilient economies and societies is the capacity of governance, formed by a set of arrangements and mechanisms to cope with, adapt to, monitoring, shape change and assessing development implications. In the complexity of the social ecosystems, the adaptive capacity of governance integrates knowledge and flexibility into the institutions sustaining human well-being and promoting resilience changes and transformation. The development of resilient economies and societies in a more complex and uncertain environment is the greater concern for policymaking, as it has been proven by the recent financial crises when green growth had intersected with resilience.

Local policies to foster the diversification in different economic sectors ensure and encourage greater urban resilience. The stakeholders engaged in the transition capacity of green growth can build the ability to support and manage the resilience of the social ecosystem and the natural resources through policy measures ensuring the sustainability of the economy and society. Resilient ecosystems contribute to the social and economic wellbeing by providing stability for industries, ecosystem services to improve the quality of life (Adger et al. 2005), and protection against disturbances. A diversified economy that is buffered from disturbances reduces the dependence from the ecosystem resilience.

Ecosystems management aimed to maintain stability in some dimensions may reduce stability in others affecting the system resilience (Gunderson and Holling 2002; Gunderson and Pritchard 2002). However, some researchers have stated that resilience is "too vague of a concept to be useful in planning" or ecosystem management (Lindenmayer and Hunter 2010). Management of complex ecosystems enhanced by knowledge of the system dynamics; the system resilience reduces uncertainty and creates responses to lessen the impacts of current disturbances. General resilience management in unknown disturbances is needed. Managing resilience uses knowledge of disturbances, to design plans, minimize damages and promote recovery. 
Long-term strategies of resilience address the global environmental crisis and their interrelationships with social, economic and environmental issues. The new green strategy is centered on resilient and green agendas focusing on nurturing greener and more inclusive green growth while reducing poverty and protecting socioecosystems and biological diversity.

Capacity building and development in urban planning, design and investment decisions allow the professionals to create, develop and manage green infrastructure. Urban policy and planning reinforce at different governance levels the potential of urban green infrastructure for engagement in urban resilience in a different community and organizational contexts, urban climate, socioeconomic and cultural settings.

Supply and deliver ecosystem services is a challenge of the management of the sustainable ecosystem in relation to the resilience of environmental and social change. Coarser and finer scale systems are levers for promoting resilience (Biggs et al. 2010). Nurturing diversity contributes to build resilience, self-organization and adaptive learning. Involvement in new urban farming practices may be an integral long-term resilience strategy (Vale and Campanella 2005).

Resilience in urban green growth requires some actions in socioecosystem management and preservation, energy security and renewal, sustainable production, distribution, and consumption, economic diversification, etc., supported by measures to deal with uncertainty, complexity and incomplete information. The resource-by-resource approach compared to the place-based approach is less amenable to resilience management. Resilience management from current priorities and decision-making processes has a lot of benefits, although agency decision making for ecosystem service result to be more complicated.

To evaluate the resilience of the system requires the identification of the regime and the impact of disturbances. The ecological resilience uses measures to predict the location and the crossing of a critical threshold in a regime shift. Also, it measures the key conditions and processes linked to system dynamics to predict the resilience and provision of the ecosystem services. In a well-known ecosystem is easier to develop the appropriate metrics for ecosystem resilience.

Engineering resilience is related to the speed of recovery quantified as the time required after the disturbance. Engineering resilience may be estimated with a system dynamics model and simulated with different levels of disturbances. Ecological and engineering resilience provides the measures of resilience with sophisticated models. However, this method of measurement has some practical limitations such as the particularity of measures to be used because resilience quantification is influenced by what is measured. To measure the speed of return, require having accurate conditions before the disturbance. Differences on the scale of disturbances result in different responses to the degree of resilience (Carpenter et al. 2001).

An agency committed to resilience management needs a firm definition, measures, a model of prediction and explanation of processes and results (Allen et al. 2011). Agencies in resilient management and adaptive management have similar challenges, need to be empowered, stakeholders must allow them (Ruhl 2012). Agencies translate the policy statements into decision making.

Maintaining biodiversity and increasing economic diversity contributes to making socioecosystems more resilient to a wide range of disturbances. Resilience ecosystems maintenance has a steady flow of ecosystem services despite the institutional and political limitations that may impede resilience management. Measuring resilience has some difficulties, among them, having signaled the standardized metrics and the identification of risk sources and targets (Carpenter et al. 2001; Haines-Young and Potschin 2010). 
Focus on economic growth, social development, poverty reduction, and sustainable environment, incorporating socioecosystem approaches increase the level of urban resilience. A more sustainable future is depending on the achievement of greater capacity for resilience to growth in the face of complex, uncertain, unforeseen changes of the socioeconomic system. The promotion of general resilience is supported by properties due to the inability to determine the type, scale, timing, and interaction of disturbances.

\section{Urban sprawl}

Over the next few decades, the world's population will reach 10 billion essentially urban and megacities housing more than 20 million residents continue to increase with intensified connectivity of economic and media links (Boone et al. 2013; Castells 2000). More functional organization and linkages of the city displaced local residents and combined order and aesthetics to develop the new structures and forms of the city sprawl and its technocratic governance. Even though the modernist development model highlighted urban sprawl changes, these changes were small compared with the accelerated speed of urban change of the time (Seto et al. 2012; Vicino et al. 2007; Zhao et al. 2006) when many cities had become post-industrial with high rates of unemployment, and loss of investments and social cohesion.

The implications of urban sprawl design in global climate change are immense in altering spatial and seasonal patterns of rainfall and sea levels (Grimm et al. 2008; McGranahan et al. 2007; Nicholls 1995; Rosenzweig et al. 2009). Global climate change threatens the urban water supply and food security, extremes the vulnerability to urban heat islands and more severe flooding (Intergovernmental Panel on Climate Change (IPCC) 2007). Relocalization of food production is part of the effort to make urban sprawl regions more sustainable and resilient by providing residents access to fresh and healthy food (Kloppenburg et al. 2000; Clancy and Ruhf 2010).

Ecological urban sprawl design is the application of ecological knowledge including issues of management and policy to landscape architecture and urban design. Metaphorical use of ecology in urban sprawl design can emphasize values such as stability, equilibrium, connectivity, wilderness (Larson 2011), while the substantive approach of urban ecology uses models and data on specific flows of energy and matter within the city (Steiner 2002) and massive flows across municipal and urban ecosystem boundaries. Urban habitat designers rely more on metaphor and analogy due to the visual and creative approach than on substantive scientific information due to the paucity of ecological research (Mostafavi and Doherty 2010; Pickett et al. 2004). Urban sprawl design is founded on conservation planning (Arendt 1996), and habitat design and greenways in biodiversity in ecology science (Lister 2007).

Urban ecology has emerged since the late 1990s moving into an integrated ecological approach with the urban green elements (Grimm et al. 2000) and urban green spaces (Sukopp et al. 1979; Szlavecz et al. 2011). The definition of urban ecology linked to environmental theory includes natural processes, components and a wide range of environmental issues (Hough 1995; Meyer 2000; Spirn 1984, 2012). Theoretical and practical urban ecological design models and projects are developed for controlled comparison and monitoring (Felson and Pickett 2005), such as the classical equilibrium paradigm of ecology. Contemporary urban ecology develops a framework and models for the entire urban system supported by social and economic sciences (Felson 2013; McGrath et al. 2007). 
Evolving, complex and contingent trajectories systems are such as urban sprawl systems are modeled by the adaptive cycle (Boone et al. 2013; Folke et al. 2012; Pickett and Grove 2009; Redman and Kinzig 2003). The adaptive cycle connects patches of shifting urban sprawl mosaics (Forman 2008) reflecting social and ecological processes, locational choices of households and institutions, and the biological and social composition and flexibility. The metacity dynamics is an open-ended model of interacting mosaics in urban sprawl transformation that may lead to unsustainable conditions (McGrath and Pickett 2011).

Landscape architects seek to improve the appearance of the city sprawl, to improve health and provide green areas and public spaces for rest and recreation for the urban population (Hough 2004).

\section{Conclusions}

The ecosystem services are a utilitarian framework promoting urban biodiversity conservation, ecosystems and human-nature interactions for more resilient cities, and to some extent a form of controlling the urban sprawl. Regional and urban resilience can be conceived as the ability to react to disruptions and disasters, integrates the psychological, physical, social, structural and environmental components of the city sprawl. Urban settlements must be encouraged to use green infrastructure approaches to address the management of the urban green and open public spaces programs to reduce greenhouse gas emissions, stormwater absorption, prevent water pollution, transform vacant lots, impervious roofs and streets into urban green spaces and habitat for biodiversity.

Urban sprawl settlements are severe pollutants of the environment while at the same time are innovative solutions to urban socioecology systems. A resilient urban community in an ideal situation on a resilient city sprawl develops synergy among the different societal sectors. In an urban sprawl resilience, the city institutions, communities, organizations and individuals develop the capacity and ability to function, survive, adapt and grow integrating some qualities of flexibility, redundancy, inclusiveness, robustness, reflectiveness, resourcefulness and responding to the disruptions and disturbances.

Green urban areas and more specifically green infrastructure are functional economic units linked by polycentric networks addressing the biodiversity and density if the urban sprawl socioecosystems. Urban sprawl management of land use interests and water supply are unrelated, and greater availability of land resources may place fewer political pressures on local land acquisitions and planning which may limit the real estate development. Urban communities sprawl should be connected to vacant land and other natural resources to increase the production and supply of healthy food.

Contexts of urban sprawl systems can be changed by designing models of urban structure and functions for the cities of the future. Urban sprawl development transformations, natural resources management and urban planning require adaptive and flexible approaches. Management of sustainable urban sprawl resilience requires better planning and policing systems taking into consideration future urban changes and the state of biodiversity and ecosystem services.

Urban sprawl sustainable planning needs energy experts to determine the level of resilience supported by data. Coordination among all the stakeholders involved in urban land use planning to meet the health and well-being needs of individual residents and urban communities in increasing densification is required. Building urban sprawl ecosystem 
resilience enables us to anticipate disasters, disturbances, stresses and shocks. Considered economic assets and green infrastructure, well-managed healthy ecosystems enhance the urban sprawl resilience to natural disasters and disturbances.

Finally, the analysis suggests that a holistic approach is required to build urban resilience based on green infrastructure by addressing a wider range of ecosystem disturbances and disasters, to create the outcomes that develop the environmental and ecological benefits of urban sprawl.

Open Access This article is licensed under a Creative Commons Attribution 4.0 International License, which permits use, sharing, adaptation, distribution and reproduction in any medium or format, as long as you give appropriate credit to the original author(s) and the source, provide a link to the Creative Commons licence, and indicate if changes were made. The images or other third party material in this article are included in the article's Creative Commons licence, unless indicated otherwise in a credit line to the material. If material is not included in the article's Creative Commons licence and your intended use is not permitted by statutory regulation or exceeds the permitted use, you will need to obtain permission directly from the copyright holder. To view a copy of this licence, visit http://creativecommons.org/licenses/by/4.0/.

\section{References}

Adger, W. N. (2000). Social and ecological resilience: Are they related? Progress in Human Geography, 24(3), 347-364.

Adger, W. N., Hughes, T. P., Folke, C., Carpenter, S. R., \& Rockstrom, J. (2005). Social-ecological resilience to coastal disasters. Science, 309, 1036-1039.

Alberti, M., Marzluff, J. M., Shulenberger, E., Bradley, G., Ryan, C., \& Zumbrunnen, C. (2003). Integrating humans into ecology: Opportunities and challenges for studying urban ecosystems. BioScience, 53, 1169-1179. https://doi.org/10.1641/0006-3568(2003)053\%5b1169:IHIEOA\%5d2.0.CO;2.

Allen, A. A., Mabile, N. J., Jaeger, D., \& Costanzo, D. (2011). The use of controlled burning during the Gulf of Mexico Deep-water Horizon (MC-252) oil spill response. In International Oil Spill Conference Proceedings (Vol. 2011). Washington, DC: American Petroleum Institute

Anderies, J. M., Walker, B. H., \& Kinzig, A. P. (2006). Fifteen weddings and a funeral: Case studies and resilience-based management. Ecology and Society, 11(1), art. 21. http://www.ecologyandsociety.org/ vol11/iss1/art21/.

Arendt, R. (1996). Conservation design for subdivisions: A practical guide to creating open space networks. Washington: Island Press.

Barnett, R., \& Margetts, J. (2013). Disturbanism in the South Pacific: Disturbance ecology as a basis for urban resilience in small island states. In S. T. A. Pickett, M. L. Cadenasso, \& B. McGrath (Eds.), Resilience in ecology and urban design: Linking theory and practice for sustainable cities (pp. 443459). New York: Springer.

Berkes, F., Colding, J., \& Folke, C. (Eds.). (2003). Navigating social-ecological systems: Building resilience for complexity and change. Cambridge, UK: Cambridge University Press.

Berkes, F., \& Folke, C. (Eds.). (1998). Linking social and ecological systems: Management practices and social mechanisms for building resilience. Cambridge, UK: Cambridge University Press.

Bhamra, R., et al. (2011). Resilience: The concept, a literature review and future directions. International Journal of Production Research, 49(18), 5375-5393.

Biggs, R., Westley, F. R., \& Carpenter, S. R. (2010). Navigating the back loop: Fostering social innovation and transformation in ecosystem management. Ecology and Society, 15(2), Article 9.

Boin, A., \& McConnell, A. (2007). Preparing for critical infrastructure breakdowns: The limits of crisis management and the need for resilience. Journal of Contingencies and Crisis Management, 15(1), 50-59.

Boone, C. G., Redman, C. L., Blanco, H., Haase, D., Koch, J., Lwasa, S., et al. (2013). Group 4: Reconceptualizing urban land use. In K. C. Seto \& A. Reenberg (Eds.), Rethinking urban land use in a global era. Cambridge: MIT Press.

Brand, F. S., \& Jax, K. (2007). Focusing the meaning (s) of resilience: Resilience as a descriptive concept and a boundary object. Ecology and Society, 12(1), 23. 
Bristow, G. (2010). Resilient regions: Re-'place'ing regional competitiveness. Cambridge Journal of Regions, Economy and Society, 3(1), 153-167.

Bruneau, M., Chang, S., Eguchi, R., Lee, G., O'Rourke, T., Reinhorn, A., et al. (2003). A framework to quantitatively assess and enhance the seismic resilience of communities. Earthquake Spectra, 19(4), $733-752$.

Cadenasso, M. L., \& Pickett, S. (2008). Urban principles for ecological landscape design and management: Scientific fundamentals. Cities and the Environment, 1(2), 1-16.

Carpenter, S., et al. (2001). From metaphor to measurement: Resilience of what to what? Ecosystems, 4(8), $765-781$.

Castells, M. (2000). The information age: Economy, society and culture, volume I: The rise of the network society. Malden, MA: Blackwell.

Chapin, F. S., III, Carpenter, S. R., Kofinas, G. P., Folke, C., Abel, N., Clark, W. C., et al. (2009). Ecosystem stewardship: Sustainability strategies for a rapidly changing planet. Trends in Ecology \& Evolution, 25, 241-249.

Clancy, K., \& Ruhf, K. (2010). Is local enough? Some arguments for regional food systems. Choices:The Magazine of Food, Farm, and Resource Issues, 25.

Cumming, G. S., Bodin, O., Ernstson, H., \& Elmqvist, T. (2010). Network analysis in conservation biogeography: Challenges and opportunities. Diversity and Distributions, 16(3), 414-425. https://doi. org/10.1111/j.1472-4642.2010.00651.x.

Cutter, S. L., Barnes, L., Berry, M., Burton, C. G., Evans, E., Tate, E. C., et al. (2008). Community and regional resilience: Perspectives from hazards, disasters, and emergency management. CARRI Research Report 1. Oak Ridge: Community and Regional Resilience Institute, http://www.resil ientus.org/library/FINAL_CUTTER_9-25-08_1223482309.pdf.

Czerniak, J. (Ed.). (2001). Appearance, performance: Landscape at downsview. In Case: Downsview park Toronto (pp. 13-23). Harvard Design School, Prestel.

Dyball, R., Brown, R. A., \& Keen, M. (2007). Towards sustainability: Five strands of social learning. In A. E. J. Wals (Ed.), Social learning towards a sustainable world-Principles, perspectives, and praxis (pp. 181-194). Wageningen Academic Publishers: Wageningen.

Ernstson, H., van der Leeuw, S. E., Redman, C. L., Meffert, D. J., Davis, G., Alfsen, C., et al. (2010). Urban transitions: On urban resilience and human-dominated ecosystems. Ambio, 39(8), 531-545. https://doi.org/10.1007/s13280-010-0081-9.

Evans, J. P. (2011). Resilience, ecology and adaptation in the experimental city. Transactions of the Institute of British Geographers, 36(2), 223-237.

Felson, A. J. (2013). The design process as a framework for collaboration between ecologists and designers. In S. T. A. Pickett, M. L. Cadenasso, \& B. McGrath (Eds.), Resilience in ecology and urban design: Linking theory and practice for sustainable cities (pp. 365-382). New York: Springer.

Felson, A. J., \& Pickett, S. T. A. (2005). Designed experiments: New approaches to studying urban ecosystems. Frontiers in Ecology and Environment, 3, 549-556.

Fisher, R. E., \& Norman, M. A. (2010). Constructing a protective measures index across the security spectrum. Journal of Business Continuity \& Emergency Planning, 4(3), 191-206. Henry Stewart Publications.

Folke, C., Carpenter, S. R., Elmqvist, T., Gunderson, L. H., Holling, C. S., Walker, B., et al. (2002). Resilience and sustainable development: Building adaptive capacity in a world of transformations. Stockholm: Ministry of the Environment.

Folke, C., Carpenter, S. R., Walker, B., Scheffer, M., Chapin, T., \& Rockström, J. (2010). Resilience thinking: Integrating resilience, adaptability and transformability. Ecology and Society, 15(4), 20. http://www.ecologyandsociety.org/vol15/iss4/ art20/

Folke, C., Carpenter, S. R., Walker, B., Scheffer, M., Chapin, T., \& Rockström, J. (2012). Resilience thinking: Integrating resilience, adaptability and transformability. Ecology and Society, 15(4), Article 20.

Folke, C., et al. (2004). Regime shifts, resilience, and biodiversity in ecosystem management. Annual Review of Ecology Evolution and Systematics, 35, 557-581.

Forman, R. T. T. (2008). Urban regions: Ecology and planning beyond the city. Cambridge: Cambridge University Press.

Fritzon, A., Ljungkvist, K., Boin, A., \& Rhinard, M. (2007). Protecting Europe's critical infrastructures: Problems and prospects. Journal of Contingencies and Crisis Management, 15(1), 30-41.

Gandy, M. (2003). Concrete and clay: Reworking nature in New York City. Cambridge: MIT Press.

Graham, S., \& Marvin, S. (2001). Splintering urbanism: Networked infrastructures, technological mobilities and the urban condition. New York: Routledge. 
Grimm, N. B., Faeth, S. H., Golubiewski, N. E., Redman, C. L., Wu, J., Bai, X., et al. (2008). Global change and the ecology of cities. Science, 319, 756-760.

Grimm, N. B., Grove, J. M., Pickett, S. T. A., \& Redman, C. L. (2000). Integrated approaches to longterm studies of urban ecological systems. BioScience, 50, 571-584.

Grünewald, F., \& Warner, J. (2012). Resilience: Buzz word or critical strategic concept? Humanitarian Aid on the Move. No. 10. Groupe URD, Plaisians.

Gunderson, L. H., \& Holling, C. S. (Eds.). (2002). Panarchy: Understanding transformations in human and natural systems. Washington, DC: Island Press.

Gunderson, L. H., Holling, C. S., Pritchard, L., Jr., \& Peterson, G. D. (2002a). Resilience of large-scale resource systems. In L. H. Gunderson \& L. Pritchard, Jr. (Eds.), Resilience and the behavior of large-scale systems (pp. 3-48).

Gunderson, L. H., \& Pritchard, L. (Eds.). (2002). Resilience and the behavior of large-scale ecosystems. Washington, DC: Island Press.

Gunderson, L. H., Pritchard, L., Jr., Holling, C. S., Folke, C., \& Peterson, G. D. (2002b). A summary and synthesis of resilience in large-scale systems. In L. H. Gunderson \& L. Pritchard Jr. (Eds.), Resilience and the behavior of large-scale systems (pp. 249-266). Washington, DC: Island Press.

Haines-Young, R., \& Potschin, M. (2010). The resilience of ecosystems to environmental change (RECCE). Overview report, 27 pp. DEFRA project code: NR0134. Available at: http://www.notti ngham.ac.uk/cem/research.htm

Hanson, C. et al., (2012). The corporate ecosystem services review: Guidelines for identifying business risks and opportunities arising from ecosystem change. Version 2.0. WRI, Washington, DC.

Hart, S., \& Milstein, M. (1999). Global sustainability and the creative destruction of industries. Sloan Management Review, 41(1).

Heerwagen, J., Durbin, N., \& Macaulay, J. (1997). Do energy efficient. Green Buildings Spell.

Hellström, T. (2007). Critical infrastructure and systemic vulnerability: Towards a planning framework. Safety Science, 45(3), 415-430.

Holling, C. S. (1973). Resilience and stability of ecological systems. Annual Review of Ecology and Systematics, 4, 1-23.

Holling, C. S. (1996). Engineering resilience versus ecological resilience. In P. C. Schulze (Ed.), Engineering within ecological constraints (pp. 31-44). Washington, DC: National Academy Press.

Holling, C. S. (2001). Understanding the complexity of economic, ecological, and social systems. Ecosystems, 4(5), 390-405.

Hough, M. (1995). Cities and natural process. London: Routledge.

Hough, M. (2004). Cities and natural process: A basis for sustainability. New York, NY: Routledge.

Hussain M. (2013). Resilience: Meaningless jargon or development solution? Guardian Online, Published Tuesday 5th March 2013. Retrieved July 6, 2015, from http://www.theguardian.com/globa 1-development-professionalsnetwork/2013/mar/05/resilience-development-buzzwords.

IPCC [Intergovernmental Panel on Climate Change]. (2007). Climate change 2007: The physical science basis. Summary for policymakers. Contribution of working group 1 to the fourth assessment report of the intergovernmental panel on climate change. Geneva, Switzerland: IPCC Secretariat, World Meteorological Organization.

IPCC (Intergovernmental Panel on Climate Change). (2014). Climate change 2014: Impacts, adaptation and vulnerability. Part A: Global and sectoral aspects. Contribution of Working Group II to the 5thAssessment Report of the IPCC. Cambridge: Cambridge University Press.

Ives, A. R., \& Carpenter, S. R. (2007). Stability and diversity of ecosystems. Science, 317, 58-62.

Kauffman, J. (2009). Advancing sustainability science: Report on the international conference on sustainability science (ICSS) 2009. Sustainability Science, , 4(2), 233-242. https://doi.org/10.1007/ s11625-009-0088-y

Kloppenburg, J., Lezberg, S., De Master, K., Stevenson, G. W., \& Hendrickson, J. (2000). Tasting food, tasting sustainability: Defining the attributes of an alternative food system with competent, ordinary people. Human Organization., 59, 177-186.

Kowarik, I. (2011). Novel urban ecosystems, biodiversity, and conservation. Environmental Pollution, 159(8-9), 1974-1983. https://doi.org/10.1016/j.envpol.2011.02.022.

Larson, B. (2011). Metaphors for environmental sustainability: Redefining our relationship with nature. New Haven: Yale University Press.

Levin, S. (1999). Fragile dominion. Cambridge, MA: Perseus Books.

Levin, S. A. (1998). Ecosystems and the biosphere as complex adaptive systems. Ecosystems, 1(5), 431-436.

Lindenmayer, D., \& Hunter, M. (2010). Some guiding concepts for conservation biology. Conservation Biology, 24(6), 1459-1468. 
Lister, N.-M. (2007). Sustainable large parks: Ecological design or designer ecology? In J. Czerniak \& G. Hargreaves (Eds.), Large parks (pp. 35-58). New York: Princeton Architectural Press.

MA (Millennium Ecosystem Assessment. (2005). Ecosystems and human well-being: Opportunities and challenges for business and industry. Washington DC: World Resources Institute.

May, R. M. (1974). Stability and complexity in model ecosystems. Princeton, NJ: Princeton University Press.

McCann, K. S. (2000). The diversity-stability debate. Nature, 405, 228-233.

McGranahan, G., Balk, D., \& Anderson, B. (2007). The rising tide: Assessing the risks of climate change and human settlements in low elevation coastal zones. Environment and Urbanization, 19(1), 17-37. https://doi.org/10.1177/0956247807076960.

McGrath, B., \& Pickett, S. T. A. (2011). The metacity: A conceptual framework for integrating ecology and urban design. Challenges, 2011(2), 55-72.

McGuire, S., \& Sperling, L. (2011). The links between food security and seed security: facts and fiction that guide response. Development in Practice, 21(4-5), 493-508.

Melosi, M. V. (2000). The sanitary city: Urban infrastructure in America from Colonial times to the present. Baltimore: Johns Hopkins University Press.

Meyer, E. (2000). The post-earth day conundrum: Translating environmental values into landscape design. In M. Conan (Ed.), Environmentalism in landscape architecture (pp. 187-244).

Mileti, D. S. (1999). Disasters by design: A reassessment of natural hazards in the United States, Natural Hazards and Disasters. Washington, D.C.: Joseph Henry Press.

Mostafavi, M., \& Doherty, G. (Eds.). (2010). Ecological urbanism. Cambridge: Lars Muller.

Musacchio, L. R. (2008). Metropolitan landscape ecology: Using translational research to increase sustainability, resilience, and regeneration. Landscape J, 28(1), 1-8.

Musacchio, L. R. (2009). Pattern: Processmetaphorsformetropolitan landscapes. In M. J. McDonnell, A. Hahs, \& J. Breuste (Eds.), Ecology of cities and towns: A comparative approach (pp. 484-502). New York: Cambridge University Press.

Naeem, S. (2002a). Disentangling the impacts of diversity on ecosystem functioning in combinatorial experiments. Ecology, 83, 2925-2935.

Naeem, S. (2002b). Ecosystem consequences of biodiversity loss: The evolution of a paradigm. Ecology, 83, $1537-1552$.

Nicholls, R. J. (1995). Coastal megacities and climate change. GeoJournal, 37(3), 369-379. https://doi. org/10.1007/BF00814018.

Olsson, P., Folke, C., \& Berkes, F. (2004). Adaptive co-management for building resilience in social-ecological systems. Environmental Management, 34, 75-90.

Pelling, M., \& Manuel-Navarrete, D. (2011). From resilience to transformation: The adaptive cycle in two Mexican urban centers. Ecology and Society, 16(2), Article 11. Retrieved from http://www.ecolo gyandsociety.org/vol16/iss2/art11/.

Peterson, G., Allen, C. R., \& Holling, C. S. (1998). Ecological resilience, biodiversity, and scale. Ecosystems, 1, 6-18.

Pickett, S. T. A., Cadenasso, M. L., \& Grove, J. M. (2004). Resilient cities: Meaning, models, and metaphor for integrating the ecological, socio-economic, and planning realms. Landscape and Urban Planning, 69, 369-384.

Pickett, S. T. A., Cadenasso, M. L., Grove, J. M., Boone, C. G., Groffman, P. M., Irwin, E., et al. (2011). Urban ecological systems: Scientific foundations and a decade of progress. Journal of Environmental Management, 92, 331-362.

Pickett, S. T. A., Cadenasso, M. L., \& McGrath, B. (Eds.). (2013a). Resilience in ecology and urban design: Linking theory and practice for sustainable cities. New York: Springer.

Pickett, S. T. A., \& Grove, J. M. (2009). Urban ecosystems: What would Tansley do? Urban Ecosystems, $12,1-8$.

Pickett, S. T. A., McGrath, B., \& Cadenasso, M. L. (2013b). The ecology of the metacity: Shaping the dynamic; patchy, networked, and adaptive cities of the future. In S. T. A. Pickett, M. L. Cadenasso, \& B. McGrath (Eds.), Resilience in ecology and urban design: Linking theory and practice for sustainable cities (pp. 463-489). New York: Springer.

Pickett, S. T. A., \& Ostfeld, R. S. (1995). The shifting paradigm in ecology. In R. L. Knight \& S. F. Bates (Eds.), A new century for natural resources management (pp. 261-278). Washington, DC: Island Press.

Pickett, S. T. A., Parker, V. T., \& Fiedler, P. L. (1992). The new paradigm in ecology: Implications for conservation biology above the species level. In P. L. Fiedler \& S. K. Jain (Eds.), Conservation biology: The theory and practice of nature conservation, preservation, and management (pp. 65-88). New York: Chapman and Hall. 
Pincetl, S. (2012). Nature, urban development and sustainability: What new elements are needed for a more comprehensive understanding? Cities, 29(S2), S32-S37.

Plummer, R., \& Armitage, D. (2007). A resilience-based framework for evaluating adaptive co-management: Linking ecology, economics and society in a complex world. Ecological Economics, 61(1), $62-74$.

Redman, C. L., \& Kinzig, A. P. (2003). Resilience of past landscapes: Resilience theory, society, and the longue duree. Conservation Ecology, 7(14), Article 14.

Resilience Alliance .(2006). http://www.resalliance.org/1.php.

Rooney, N., McCann, K., Gelner, G., \& Moore, J. C. (2006). Structural asymmetry and the stability of diverse food webs. Nature, 442, 265-269.

Rosenzweig, C., Solecki, W., Blake, R., Bowman, M., Castaldi, A., Faris, C., et al. (2009). Climate risk information: New York City Panel on Climate Change. New York, NY: New York City Panel on Climate Change.

Ruhl, J. B. (2012). Panarchy and the law. Ecology and Society, 17(3), 31.

Scheffer, M., Carpenter, S. R., Lenton, T. M., Bascompte, J., Brock, W., Dakos, V., et al. (2012). Anticipating critical transitions. Science, 338(6105), 344-348.

Seto, K. C., Reenberg, A., Boone, C. G., Fragkias, M., Haase, D., Langanke, T., et al. (2012). Urban land teleconnections and sustainability. Proceedings of the National Academy of Sciences of the United States of America, 109(20), 7687-7692.

Shannon, K. (2013). Eco-engineering for water: From soft to hard and back. In S. T. A. Pickett, M. L. Cadenasso, \& B. McGrath (Eds.), Resilience in ecology and urban design: Linking theory and practice for sustainable cities (pp. 163-182). New York.

Simmie, J., \& Martin, R. (2010). The economic resilience of regions: Towards an evolutionary approach. Cambridge Journal of Regions, Economy and Society, 3, 27-43.

Spirn, A. W. (1984). Granite garden: Urban nature and human design. New York: Basic Books.

Spirn, A. W. (2012). Ecological urbanism: A framework for the design of resilient cities. Retrieved from Steiner, F. R. (2002). Human ecology: Following nature's lead. Washington, DC: Island Press.

Steiner, F. R. (2002). Human ecology: Following nature's lead. Washington, DC: Island.

Sukopp, H., Trautmann, W., \& Korneck, D. (1979). The soil flora and vegetation of Berlin'swastelands. In I. Laurie (Ed.), Nature in Cities. Chichester: Wiley.

Szlavecz, K., Warren, P., \& Pickett, S. (2011). Biodiversity on the urban landscape. In R. P. Cincotta \& L. J. Gorenflo (Eds.), Human population: Its influences on biological diversity, vol 1650, Part 1. New York: Springer.

Tilman, D. (1996). Biodiversity: Population versus ecosystem stability. Ecology, 77(2), 350-363.

Tilman, D., \& Downing, J. A. (1994). Biodiversity and stability in grasslands. Nature, 367, 363-365.

Tilman, D., \& Downing, J. A. (1996). Biodiversity and stability in grasslands. In F. B. Samson \& F. L. Knopf (Eds.), Ecosystem management (pp. 3-7). New York: Springer.

Tilman, D., Polasky, S., \& Lehman, C. (2005). Diversity, productivity and temporal stability in the economies of humans and nature. Journal of Environmental Economics and Management, 49(3), 405-426.

Tilman, D., Reich, P., \& Knops, J. (2006). Biodiversity and ecosystem stability in a decade-long grassland experiment. Nature, 441, 629-632. https://doi.org/10.1038/nature04742.

Tilman, D., Wedin, D., \& Knops, J. (1996). Productivity and sustainability influenced by biodiversity in grassland ecosystems. Nature, 379, 718-720.

Turner, B. L., Kasperson, R. E., Matson, P. A., McCarthy, J. J., Corell, R. W., Christensen, L., et al. (2003). A framework for vulnerability analysis in sustainability science. Proceedings of the National Academy of Sciences, 100(14), 8074-8079. https://doi.org/10.1073/pnas.1231335100.

Un, FAO (United Nations Food and Agriculture Organisation). (2012). Measuring resilience: A concept note on the resilience tool. Rome: FAO.

Vale, L. J., \& Campanella, T. J. (Eds.). (2005). The resilient city: How modern cities recover from disaster (p. 392). Oxford: Oxford University Press.

van Nes, E. H., \& Scheffer, M. (2007). Slow recovery from perturbations as a generic indicator of a nearby catastrophic shift. American Naturalist, 169(6), 738-747.

Vicino, T. J., Hanlon, B., \& Short, J. R. (2007). Megalopolis 50 years on: The transformation of a city region. International Journal of Urban and Regional Research, 31(2), 344-367.

Walker, B., Holling, C. S., Carpenter, S. R., \& Kinzig, A. (2004). Resilience, adaptability and transformability in social-ecological systems. Ecology and Society, 9(2), 5.

Walker, B., \& Salt, D. (2006). Resilience thinking: Sustaining ecosystems and people in a changing world. Washington: Island Press.

Walker, B., \& Salt, D. (2012). Resilience practice: Engaging the sources of our sustainability. Washington, DC: Island Press. 
Walker, B., et al. (2006). A handful of heuristics and some propositions for understanding resilience in social-ecological systems. Ecology and Society, 11(1), 13.

Wieski, K., Guo, H., Craft, C. B., \& Pennings, S. C. (2010). Ecosystem functions of tidal fresh, brackish, and salt marshes on the Georgia coast. Estuar Coast, 33, 161-169.

Wu, J., \& Wu, T. (2013). Ecological resilience as a foundation for urban design and sustainability. In S. Pickett, M. Cadenasso, \& B. McGrath (Eds.), Resilience in ecology and urban design. Future city (Vol. 3). Dordrecht: Springer.

Yaverbaum, G. (1989). Specifying system requirements: a framework of current techniques. Journal of Information Systems Management, 6(1), 17-21.

Zhao, S., Da, L., Tang, Z., Fang, H., Song, K., \& Fang, J. (2006). Ecological consequences of rapid urban expansion: Shanghai, China. Frontiers in Ecology and Environment, 4, 341-346.

Publisher's Note Springer Nature remains neutral with regard to jurisdictional claims in published maps and institutional affiliations. 